\section{Functional turnover from lowland to montane forests: evidence from the Hyrcanian forest in northern Iran}

\author{
Seyed Mohammad Jafari ${ }^{(1)}$, Shahin Zarre ${ }^{(1)}$, Seyed Kazem Alavipanah ${ }^{(2)}$, \\ Farrokh Ghahremaninejad ${ }^{(3)}$
}

Plant functional traits and functional diversity play a key role in forest ecosys tems. Altitudinal patterns of plant functional diversity are poorly investigated in the Hyrcanian relict forest, northern Iran. In this study, differences in trait composition between lowland and montane forest types were analyzed. Variation of plant functional traits along a $2400 \mathrm{~m}$ altitudinal gradient was examined in 67 vegetation sampling plots established at different elevations along the gradient. Eight plant functional traits related to plant physiognomy, competitive ability and dispersal were considered for 174 recorded vascular plants. We used generalized linear model, principal coordinate analysis and functional diversity metrics to investigate functional changes along the gradient. The importance of different traits such as the chamaephyte life form, tiny leaves, dry indehiscent fruits and small seeds increase with altitude. In contrast, other traits including large leaves, maximum height of plants, fleshy fruits, anemophily as well as medium to large seeds decrease with increasing elevation. Our findings support the existence of strong functional differences between lowland and montane forest vegetation types. Trait associations, different environmental parameters, disturbances and especially elevation were discussed as important predictors of functional changes. Vegetation type is a key factor affecting functional diversity variation in temperate forests. Therefore, we strongly recommend exploring and considering functional diversity in forest management practices.

Keywords: Functional Diversity, Gradient, Hyrcanian Forest, Multivariate Analysis, Vegetation

\section{Introduction}

Exploring the heterogeneous distribution of biological diversity and ecological communities in the biosphere has long been a core objective in ecological studies (Gaston 2000). Plant functional traits, as link factors of biological diversity to ecosystem functioning, are attributes with significant influence on establishment, survival and fitness of plant species in the ecosystem (Diaz \& Cabido 2001). Such traits vary both along the en- vironmental gradients and among species occupying similar habitat conditions (Cornwell \& Ackerly 2009). Some functional traits are advantageous under specific environmental conditions, and they are prevalently represented by species groups which grow under such conditions (Diaz et al. 1998, Pellissier et al. 2010).

Elevation gradients are among the most interesting tools for exploring the distribution patterns of biological diversity (Rahbek
1995), in that certain factors (such as general geological characteristics and evolutionary history of species) are constant, while others may abruptly change at short distance (e.g., temperature, radiation, precipitation, season length, etc.), making elevation gradients an ideal test system for understanding the ecosystems responses to environmental changes (Körner 2000, Fischer et al. 2011).

Studies on the association between plant traits and habitat conditions along environmental gradients have a long history (Körner 1999, Duckworth et al. 2000), and may provide important hints on the processes and mechanisms governing species distribution, richness pattern, community assembly and ecosystem functioning (Lavorel \& Garnier 2002). Due to complexity of the observed variation in plant traits, at least for elevation gradients, plant ecologists still debate over the generality of the patterns found (Körner et al. 2007). Some factors such as co-presence of environmental sub-gradients including temperature, precipitation and radiation, human interference including land use/land cover changes, phylogenetic bias in trait variation, surface area, season length, along with community composition, stand age, and competition are among the major causes of the aforementioned complexity (Körner 2000).

Lowland forests present significant differences in trait composition as compared with montane forest. We hypothesized that the vegetation type may play a key role in the functional turnover along the elevational gradient. Montane and lowland forest ecosystems represent either a different set of plant functional traits or similar traits with different importance values. Our aims were to answer the following key questions: (1) Does functional trait composition differs between lowland and montane forests? (2) Which ecological drivers, including forest compositional and physiognomic properties, cause functional differences between lowland and montane forest types? (3) How and why the distribution of different plant functional traits change with altitude?

\section{Material and Methods}

\section{Study area and sampling}

Hyrcanian forest is a temperate deciduous forest ecosystem in the southeastern part of the Caucasus biodiversity hotspot, northern Iran. This unique ecosystem belongs to Euro-Siberian floristic region (Takhtajan 1986) and hosts relict flora which has survived the Quaternary glaciations (Leroy \& Arpe 2007). In spite of its limited extension, Hyrcanian forest along with adjacent mountains hosts about $44 \%$ of the Iranian flora (more than 3000 taxa - Akhani et al. 2010).

Hyrcanian forest suffers from numerous

Communicated by: Giustino Tonon 


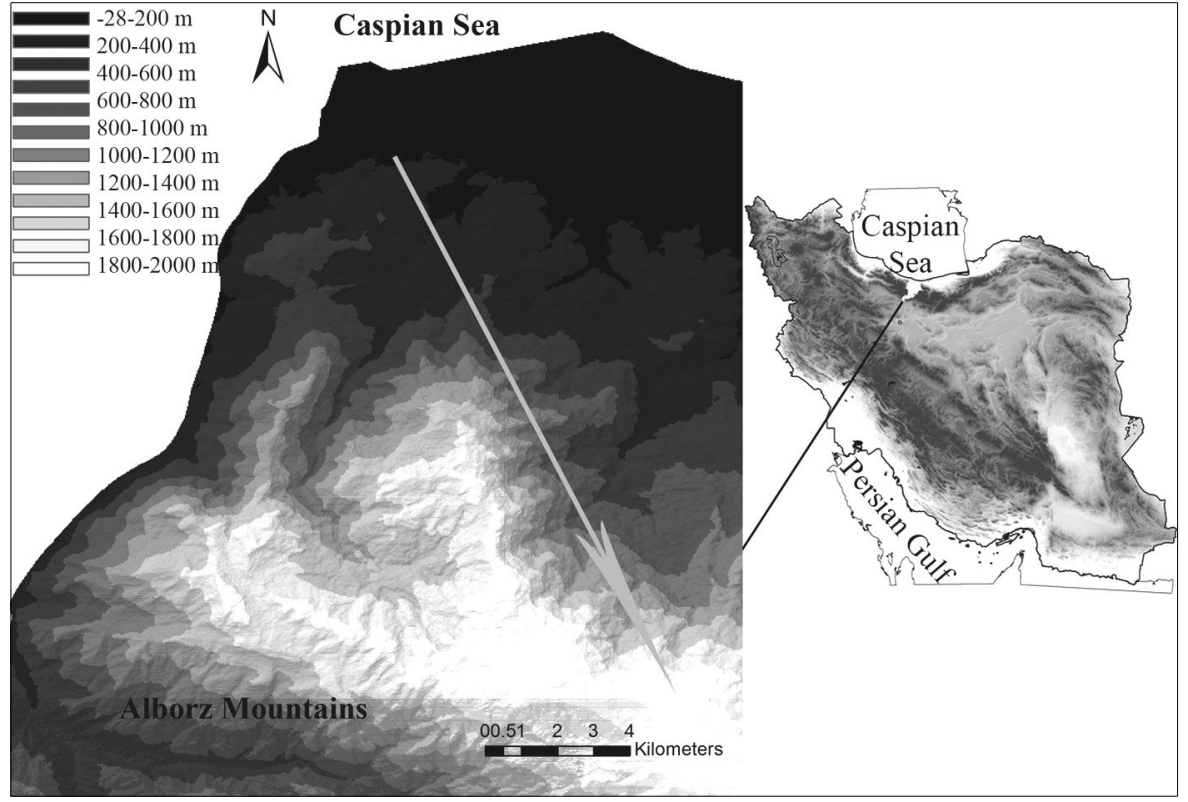

Fig. 1 - Geographic location of the study area in northern Iran, with the elevation transect (grey arrow) located on the Central Alborz Mountains.

natural and anthropogenic threats including improper management, wood harvesting activities, flood, fire, land use/land cover changes, husbandry and intense grazing (especially in the montane part). Currently, about 40 conservation areas are partly or completely located in this region.

Precipitation in this area decreases from about $1300 \mathrm{~mm}$ in the northern part to 800 $\mathrm{mm}$ at $2400 \mathrm{~m}$ elevation peak in the south (Bastl et al. 2008). The mean annual temperature decreases from $16.1{ }^{\circ} \mathrm{C}$ in the northern part to $10{ }^{\circ} \mathrm{C}$ in southwest and to $12.2{ }^{\circ} \mathrm{C}$ in the southeastern part. General climatic conditions abruptly change from very humid at the northern limit to the Mediterranean-like climate in the southern part. Maximum precipitation occurs in September-December in the north and March-May in the south (IRIMO 2012).

Tab. 1 - Characteristics of the elevational belts considered along the main altitudinal gradient in the Hyrcanian forest. (LoF): Lowland Forest; (MiF): Mid-altitude Forest; (MoF): Montane Forest.

\begin{tabular}{lccccc}
\hline $\begin{array}{l}\text { Elevational } \\
\text { belt }\end{array}$ & $\begin{array}{c}\text { Altitudinal range } \\
(\mathbf{m})\end{array}$ & $\begin{array}{c}\text { Surface Area } \\
\left.\mathbf{( m}^{\mathbf{2}}\right)\end{array}$ & Plots & $\begin{array}{c}\text { No. } \\
\text { Species }\end{array}$ & $\begin{array}{c}\text { Vegetation } \\
\text { Type }\end{array}$ \\
\hline Belt1 & $0-200$ & 52192295.40 & 5 & 92 & LoF \\
Belt2 & $200-400$ & 59860284.44 & 7 & 87 & LoF \\
Belt3 & $400-600$ & 56189891.22 & 7 & 89 & LoF \\
Belt4 & $600-800$ & 54236731.49 & 5 & 81 & LoF \\
Belt5 & $800-1000$ & 54298613.78 & 5 & 70 & MiF \\
Belt6 & $1000-1200$ & 56390235.12 & 7 & 71 & MiF \\
Belt7 & $1200-1400$ & 60473692.62 & 7 & 73 & MiF \\
Belt8 & $1400-1600$ & 65444387.42 & 7 & 71 & MiF \\
Belt9 & $1600-1800$ & 39392717.61 & 5 & 69 & MoF \\
Belt10 & $1800-2000$ & 20546466.74 & 4 & 64 & MoF \\
Belt11 & $2000-2200$ & 10217539.31 & 4 & 52 & MoF \\
Belt12 & $2200-2400$ & 2856641.13 & 4 & 40 & MoF \\
\hline
\end{tabular}

by cold sensitive taxa such as Parrotia persica C.A.Mey, Quercus castaneifolia C.A. Mey., Carpinus betulus L., Acer velutinum Boiss., Tilia platyphyllos Scop. and evergreen broadleaf shrubs such as Buxus hyrcana Pojark. and Prunus laurocerasus L. Montane forests is more heterogeneous and dominates above $1600 \mathrm{~m}$ a.s.l. It is mainly characterized by the presence of Fagus orientalis Lipsky at mid-altitudes, Quercus macranthera Fisch. \& C.A.Mey. at higher elevations, and a transitional Fagus-Quercus forest vegetation in between.

Major land use/land cover categories in lowlands are deciduous forest, orchards, agriculture and urban land cover classes. Mid-altitude habitats are characterized by deciduous forests, fragmented to some extent due to local husbandry and ranching activities in forest openings. Lowland forests have been subject to anthropogenic disturbance during last few decades due to easy accessibility (Poorzady \& Bakhtiari 2009). Generally, disturbance intensity decreases from lowland to mid-altitudes, and increases again in montane forests (Jafari et al. 2013). The montane forests are characterized by a lower stem density, and gradually shifts into montane shrublands and rangelands, due to the increasing intensity of grazing with the elevation.

\section{Sampling}

Based on the results of former floristic and vegetation studies (Jafari et al. 2013), the selected gradient was split in three altitudinal zones $(0-800 \mathrm{~m}, 800-1600 \mathrm{~m}, 1600-2400 \mathrm{~m}$ a.s.l.) covered by lowland (LoF), mid-altitude $(\mathrm{MiF})$ and montane $(\mathrm{MoF})$ forests, respectively. Each zone was further divided in four $200 \mathrm{~m}$ altitudinal belts, and 4 to $7 \mathrm{sam}$ pling plots $\left(20 \times 20 \mathrm{~m}-400 \mathrm{~m}^{2}\right)$ were established within each belt in homogenous, mature and undisturbed forest stands (Tab. 1). Overall, 67 sampling plots were established along the above gradient.

Vegetation and species composition for each plot were recorded during 2009-2010 vegetative seasons using the Braun-Blanquet approach (Braun-Blanquet 1932). Diameter at breast height $(\mathrm{DBH})$ and tree ring width data were used to estimate the age of dominant forest species. Overall, 174 species of vascular plants were recorded (see Appendix 1). Taxonomic status of all taxa was double checked using published and online resources (Clayton et al. 2006).

\section{Plant functional traits}

Plant traits related to physiognomy, productivity, competitive ability, dispersal and reproduction were considered in this analysis (Tab. 2). For each species in each plot three mature leaves were collected, and the leaf area measured by scanning using the image analyzer CAMPU EYE LSA software (Bakr 
Tab. 2 - Plant functional traits related to plant physiognomy, competitive ability and dispersal in Hyrcanian forest (Assadi et al. 1988, Kleyer et al. 2008, Klotz et al. 2002, Rechinger 1963, Royal Botanical Gardens Kew 2008). (a): Quantitative traits were transformed to multi-class traits for GLM analysis.

\begin{tabular}{|c|c|c|}
\hline Trait group & Trait Type & Traits \\
\hline Life form & Categorical & $\begin{array}{l}\text { Phanerophyte (LFPhan), Chamaephyte (LFCham), Hemicryptophyte (LFHemi), Geophyte (LFGeop), } \\
\text { Therophyte (LFTher), Fern (LFFern), Liana/Climber (LFLian), Hydrophyte (LFHydr) }\end{array}$ \\
\hline $\begin{array}{l}\text { Maximum } \\
\text { Height }\end{array}$ & Quantitative & MH (m) [Categories: MH1 (<0.5 m), MH2 (0.5-1 m), MH3 (1-6 m), MH4 (6-20 m), MH5 (>20 m) \\
\hline Leaf Type & Categorical & Simple leaves (LTSimp), Compound leaves (LTComp) \\
\hline $\begin{array}{l}\text { Mean Leaf } \\
\text { Area }\end{array}$ & Quantitative & $\begin{array}{l}\text { MLA }\left(\mathrm{cm}^{2}\right) \text { [Categories: MLA1 }\left(<1 \mathrm{~cm}^{2}\right) \text {, MLA2 }\left(1-2 \mathrm{~cm}^{2}\right) \text {, MLA3 }\left(2-4 \mathrm{~cm}^{2}\right) \text {, MLA4 }\left(4-6 \mathrm{~cm}^{2}\right) \text {, MLA5 } \\
\left(6-8 \mathrm{~cm}^{2}\right) \text {, MLA6 }\left(8-10 \mathrm{~cm}^{2}\right), \text { MLA7 }\left(10-15 \mathrm{~cm}^{2}\right) \text {, MLA8 }\left(15-25 \mathrm{~cm}^{2}\right) \text {, MLA9 }\left(25-40 \mathrm{~cm}^{2}\right), \text { MLA10 } \\
\left(40-70 \mathrm{~cm}^{2}\right) \text {, MLA11 }\left(70-100 \mathrm{~cm}^{2}\right) \text {, MLA12 }\left(100-200 \mathrm{~cm}^{2}\right), \text { MLA13 }\left(>200 \mathrm{~cm}^{2}\right)\end{array}$ \\
\hline Seasonality & Categorical & $\begin{array}{l}\text { Woody deciduous (SWDeci), Woody evergreen (SWEver), Perennial (SPere), Biennial (SBien), Annual } \\
\text { (SAnnu) }\end{array}$ \\
\hline Fruit type & Categorical & Fleshy (FTFles), Dry Dehiscent (FTDDe), Dry Indehiscent (FTDIn), Without Fruit (FTNone) \\
\hline Pollination & Categorical & Entomophily (PEnto), Anemophily (PAnem), Hydrophily (PHydr), Self-Pollination (PSelf) \\
\hline Seed Weight & Quantitative & $\begin{array}{l}\text { SW (mg of } 1000 \text { seeds). Categories: SW1 (<1 mg), SW2 (1-2 mg), SW3 (2-3 mg), SW4 (3-4 mg), SW5 } \\
\text { (4-5 mg), SW6 (5-10 mg), SW7 (10-20 mg), SW8 (20-50 mg), SW9 (50-100 mg), SW10 (100-200 mg), } \\
\text { SW11 ( }>200 \mathrm{mg}) \text {, SW12 (No seeds) }\end{array}$ \\
\hline
\end{tabular}

2005). Maximum plant height was assessed for each species in each plot using standard stick methods, and then averaged over plots to obtain a mean value for each species in each belt. As for pollination mechanism, species were assigned to the categories listed in Tab. 2 based on the information obtained from available databases (such as BIOLFLORE plant trait database - Klotz et al. 2002, and Interaction Web Database), except for 7 species for which it was determined based on field observations. For 5 species no information was available at all. Mean seed weight for each species was obtained from the SEED Information Database (Royal Botanical Gardens Kew 2008) and LEDA Traitbase (Kleyer et al. 2008). The seed weight trait represents the weight of 1000 seeds in gram. For plant taxa not listed in the above databases, the mean value of the closest relative species (when available) was considered. Each species was assigned to life form categories based on the authors' field experience and checked a posteriori using online resources (Klotz et al. 2002, Kleyer et al. 2008).

\section{Data analysis}

Values for quantitative traits were grouped into categorical classes. Categorization was primarily implemented using frequency of range values within our dataset.

Data collected were arranged in two "state" matrices of 174 species $\times 12$ belts and 174 species $\times 60$ traits, and then combined to obtain a 12 belts $\times 60$ traits state matrix, according to the method proposed by Diaz et al. (1998). Cover-abundance values for each species were averaged over plots in each belt and used as belt-wise weighting factor in that belt. After weighting species in each belt, the frequency of each trait category was calculated and converted to proportion, and then transformed by the arcsine function prior to analysis (Sokal \& Rohlf 1995).
A generalized linear model function (normal distribution with identity link) was applied by the software package SPSS 20.0 (IBM Corp 2011) using the proportion of the trait states as dependent variable, and the mean elevation of each belt as predictor.

In order to analyze the variation in the composition of functional traits along the elevation gradient, principal coordinate analysis (PCoA - Gower 1966) was applied on a pairwise belt-to-belt dissimilarity matrix based on Gower's coefficients (because of the categorical nature of the dataset - Gower 1971) using the PAST software package (Hammer et al. 2001). UPGMA clustering method using the Gower's coefficient matrix was adopted to re-test the PCoA results. In addition, several functional metrics, such as the modified attribute functional diversity (MFAD - Schmera et al. 2009) and the community based functional diversity index (FDc - Petchy \& Gaston 2006), were calculated for each altitudinal belt using the FDIVERSITY software (Casanoves et al. 2011) and then compared. MFAD may take values in the range $0-1$ and it was calculated as follows (Pla et al. 2012 - eqn. 1):

$$
M F A D=\frac{\sum_{i=1}^{N} \sum_{j>1}^{N} d_{i j}}{N}
$$

where $d_{\mathrm{ij}}$ is the Gowers' dissimilarity between functional units $i$ and $j$, and $N$ is the number of functional units. This index reduces the matrix dimensions by summarizing similar species as functional units, providing a simple numerical index to compare communities in the functional space (Schmera et al. 2009). $F D c$ is a dendrogram-based index, and equals the total length of the branches of the dendrogram constructed from information on species functional traits (Petchy \& Gaston 2006). Moreover, Shannon's index of taxonomic diversity $\left(H^{\prime}\right)$ was calculated for each belt as follows (eqn. 2):

$$
H^{\prime}=-\sum_{i=1}^{S} p_{i} \ln p_{i}
$$

where $p_{\mathrm{i}}$ is the relative importance value of the $i$-th species and $S$ is the total number of species.

\section{Results}

\section{Leaf size and type}

Despite the prevalence of species with simple leaf type in comparison with compound leaf type in both lowland and montane forests, the proportion of both leaf types showed negligible changes with altitude and forest type (Tab. 3, Fig. 2a). The relative abundance of medium and large leaf classes (MLA8, MLA10, MLA11, MLA12 and MLA13) showed a meaningful negative correlation with altitude (Tab. 3 , Fig. $2 \mathrm{~m}, \mathrm{n})$. The proportion of small leaved species significantly increased from lowland to montane forests (MLA1: $\mathrm{B}=3.921, \mathrm{P}<0.05$; MLA2: $\mathrm{B}=4.835, \mathrm{P}<0.05$; MLA3: $\mathrm{B}=4.119, \mathrm{P}<0.05$; MLA4: $\mathrm{B}=5.667, \mathrm{P}<0.05$ ) (Fig. $2 \mathrm{k}, 1$ ). Patterns of change at mid-altitudes for mean leaf area trait differed from the patterns at the gradient extremes. For example, an increase in the frequency of classes MLA8, MLA9 and MLA13 was observed at mid elevations, as well as a reduction in proportion for classes MLA3, MLA4 and MLA11 (Fig. $2 \mathrm{k}, 1, \mathrm{~m}, \mathrm{n})$.

\section{Life form, seasonality and maximum height}

As for life form traits, the importance of geophytes and ferns showed a non-significant decrease with elevation $(\mathrm{B}=-2.180, \mathrm{P}=$ $0.107 ; \mathrm{B}=-3.331, \mathrm{P}=0.183$, respectively Fig. $2 b, c)$. Moreover, ferns do not produce 
fruits and the proportion of the "FTNone" class decreased non-significantly with altitude $(B=-3.331, P=0.183)$. On the contrary, the proportion of chamaephytes significantly increased with altitude along the gradient (B $=4.187, \mathrm{P}<0.05)$. Generally, phanerophytes showed non-significant (or marginally signi-

ficant) relationship with altitude $(\mathrm{B}=-4.509$, $\mathrm{P}=0.061)$. However, a significant decrease of woody deciduous taxa $(\mathrm{B}=-3.854, \mathrm{P}<$ 0.05 ) was observed from lowland to high altitude forests (Fig. 2f). Furthermore, a nonsignificant variation in the proportion of woody evergreens (usually shrubs, e.g., pha-

Tab. 3 - Generalized linear model correlation between proportion of plant functional traits and altitude in the Hyrcanian forest. (WMP): Weighted mean proportion; (LF): Lowland forest; (MF): Montane forest. $(*): \mathrm{p}<0.05 ;(* *): \mathrm{p}<0.01 ;(* * *)$ : $\mathrm{p}<0.001$.

\begin{tabular}{|c|c|c|c|c|c|}
\hline \multirow{2}{*}{$\begin{array}{l}\text { Trait } \\
\text { group }\end{array}$} & \multirow{2}{*}{ Trait } & \multicolumn{2}{|c|}{ Altitude } & \multirow{2}{*}{$\mathbf{L F}$} & \multirow{2}{*}{ MF } \\
\hline & & B & P-value & & \\
\hline \multirow[t]{2}{*}{ Leaf type } & Simple leaf(LTSimp) & 2.093 & 0.150 & 0.800 & 0.820 \\
\hline & Compound leaf(LTComp) & -2.093 & 0.150 & 0.200 & 0.180 \\
\hline \multirow[t]{7}{*}{ Life form } & Phanerophyte (LFPhan) & -4.509 & 0.061 & 0.432 & 0.366 \\
\hline & Chamaephyte (LFCham) & 4.187 & $0.005 * *$ & 0.017 & 0.037 \\
\hline & Hemicryptophyte (LFHemi) & 2.146 & 0.323 & 0.372 & 0.403 \\
\hline & Geophyte (LFGeop) & -2.180 & 0.107 & 0.073 & 0.052 \\
\hline & Therophyte (LFTher) & 3.718 & 0.130 & 0.053 & 0.083 \\
\hline & Fern (LFFern) & -3.331 & 0.183 & 0.027 & 0.023 \\
\hline & Liana/climber (LFLian) & 6.124 & 0.806 & 0.024 & 0.033 \\
\hline \multirow{5}{*}{$\begin{array}{l}\text { Maximum } \\
\text { height }\end{array}$} & Maximum Height $<0.5 \mathrm{~m}(\mathrm{MH} 1)$ & 4.186 & 0.045 & 0.126 & 0.351 \\
\hline & Maximum Height $0.5-1 \mathrm{~m}$ (MH2) & 9.721 & 0.563 & 0.193 & 0.216 \\
\hline & Maximum Height 1-6 m (MH3) & -6.315 & 0.055 & 0.294 & 0.204 \\
\hline & Maximum Height 6-20 m (MH4) & -4.260 & $0.038^{*}$ & 0.173 & 0.054 \\
\hline & Maximum Height $>20$ m (MH5) & -6.750 & 0.061 & 0.241 & 0.198 \\
\hline \multirow{13}{*}{$\begin{array}{l}\text { Mean leaf } \\
\text { area }\end{array}$} & Mean Leaf Area $<1 \mathrm{~cm}^{2}($ MLA1) & 3.921 & $0.000 * * *$ & 0.031 & 0.213 \\
\hline & Mean Leaf Area 1-2 $\mathrm{cm}^{2}$ (MLA2) & 4.835 & $0.002 * *$ & 0.042 & 0.097 \\
\hline & Mean Leaf Area 2-4 $\mathrm{cm}^{2}$ (MLA3) & 4.119 & $0.031 *$ & 0.034 & 0.123 \\
\hline & Mean Leaf Area 4-6 $\mathrm{cm}^{2}$ (MLA4) & 5.667 & $0.022 *$ & 0.065 & 0.164 \\
\hline & Mean Leaf Area 6-8 $\mathrm{cm}^{2}$ (MLA5) & 9.998 & 0.835 & 0.048 & 0.051 \\
\hline & Mean Leaf Area 8-10 $\mathrm{cm}^{2}$ (MLA6) & 2.931 & 0.051 & 0.050 & 0.081 \\
\hline & Mean Leaf Area $10-15 \mathrm{~cm}^{2}$ (MLA7) & 8.789 & 0.221 & 0.113 & 0.115 \\
\hline & Mean Leaf Area $15-25 \mathrm{~cm}^{2}$ (MLA8) & -6.002 & $0.048^{*}$ & 0.211 & 0.125 \\
\hline & Mean Leaf Area $25-40 \mathrm{~cm}^{2}$ (MLA9) & 5.128 & 0.128 & 0.109 & 0.111 \\
\hline & Mean Leaf Area $40-70 \mathrm{~cm}^{2}$ (MLA10) & -5.660 & $0.001 * *$ & 0.357 & 0.114 \\
\hline & Mean Leaf Area 70-100 $\mathrm{cm}^{2}$ (MLA11) & -2.732 & $0.019 *$ & 0.182 & 0.0 .91 \\
\hline & Mean Leaf Area $100-200 \mathrm{~cm}^{2}$ (MLA12) & -6.543 & $0.030^{*}$ & 0.110 & 0.070 \\
\hline & Mean Leaf Area $>200 \mathrm{~cm}^{2}$ (MLA13) & -2.211 & $0.004 * *$ & 0.029 & 0.033 \\
\hline \multirow[t]{5}{*}{ Seasonality } & Woody deciduous (SWDeci) & -3.854 & $0.028 *$ & 0.375 & 0.327 \\
\hline & Woody evergreen (SWEver) & -3.397 & 0.338 & 0.065 & 0.040 \\
\hline & Perennial (SPere) & 1.276 & 0.580 & 0.485 & 0.502 \\
\hline & Biennial (SBienn) & 3.678 & $0.025^{*}$ & 0.025 & 0.047 \\
\hline & Annual (SAnnu) & 3.718 & 0.130 & 0.052 & 0.085 \\
\hline \multirow[t]{4}{*}{ Fruit type } & Fleshy (FTFles) & -7.730 & $0.016^{*}$ & 0.230 & 0.146 \\
\hline & Dry dehiscent (FTDDe) & 2.447 & 0.923 & 0.266 & 0.262 \\
\hline & Dry indehiscent (FTDIn) & 5.595 & $0.001 * *$ & 0.475 & 0.567 \\
\hline & Without fruit (FTNone) & -3.331 & 0.183 & 0.027 & 0.023 \\
\hline \multirow{4}{*}{$\begin{array}{l}\text { Pollination } \\
\text { mechanism }\end{array}$} & Entomophily (PEnto) & 5.485 & 0.926 & 0.612 & 0.582 \\
\hline & Anemophily (PAnem) & -5.923 & 0.052 & 0.330 & 0.250 \\
\hline & Hydrophily (PHydr) & 4.387 & 0.623 & 0.027 & 0.015 \\
\hline & Self-pollination (PSelf) & -5.148 & 0.052 & 0.032 & 0.017 \\
\hline \multirow{12}{*}{$\begin{array}{l}\text { Seed weight } \\
\text { (mg x } 1000 \\
\text { seeds) }\end{array}$} & Seed weight $<1 \mathrm{mg}(\mathrm{SW} 1)$ & 5.442 & $0.002 * *$ & 0.107 & 0.162 \\
\hline & Seed weight 1-2 mg (SW2) & -8.663 & 0.518 & 0.132 & 0.120 \\
\hline & Seed weight 2-3 mg (SW3) & 4.854 & $0.030^{*}$ & 0.060 & 0.010 \\
\hline & Seed weight 3-4 mg (SW4) & -6.981 & $0.021 *$ & 0.010 & 0.052 \\
\hline & Seed weight 4-5 mg (SW5) & -4.421 & $0.000 * * *$ & 0.077 & 0.047 \\
\hline & Seed weight 5-10 mg (SW6) & 4.558 & $0.012 *$ & 0.052 & 0.080 \\
\hline & Seed weight $10-20 \mathrm{mg}$ (SW7) & -9.338 & 0.776 & 0.067 & 0.065 \\
\hline & Seed weight $20-50 \mathrm{mg}$ (SW8) & -3.489 & 0.056 & 0.087 & 0.070 \\
\hline & Seed weight $50-100 \mathrm{mg}(\mathrm{SW} 9)$ & -5.038 & 0.830 & 0.082 & 0.087 \\
\hline & Seed weight $100-200 \mathrm{mg}$ (SW10) & -1.529 & 0.556 & 0.112 & 0.105 \\
\hline & Seed weight $>200 \mathrm{mg}$ (SW11) & 5.667 & 0.701 & 0.095 & 0.100 \\
\hline & No seeds (SW12) & -8.427 & 0.101 & 0.027 & 0.025 \\
\hline
\end{tabular}

nerophyte or chamaephyte life forms) was detected along the altitudinal gradient $(\mathrm{B}=$ $-3.397, \mathrm{P}=0.338$ - Fig. 2f).

Annual species or therophytes showed a non-significant but non-negligible increase in proportion from lowland to montane forests $(\mathrm{B}=3.718, \mathrm{P}=0.130)$. Hemicryptophytes (including forbs and non-rhizomatous grasses) were dominant in both vegetation types and their importance rises from lowland to montane type $(0.372$ vs. $0.403 \mathrm{WMP}$ - Tab. 3, Fig. 2d, e). Generally, the proportion of herbaceous taxa (including annual, biennial and perennial species) increased non-linearly with altitude, while perennials and annuals showed an opposite pattern of change at mid-altitudes. In contrast to perennials, annuals decreased in proportion at mid-altitude sites, then rise up again in the montane forest type (Fig. 2e).

Concerning maximum height, all classes showed a significant correlation with altitude (Fig. $2 \mathrm{~g}, \mathrm{~h})$, except MH2 (0.5 to $1 \mathrm{~m})$. For example, herbaceous plants (class MH1) increase their importance along the altitudinal gradient $(\mathrm{B}=4.186, \mathrm{P}<0.05)$. Shrub species (MH3, 1-6 m of maximum height) presented a small decrease from low to high altitudes (0.296 to $0.256 \mathrm{WMP})$. As expected, tall woody plants (MH4 and MH5) significantly decrease in importance with altitude (Fig. 2h, Tab. 3).

\section{Fruits, pollination and seed traits}

Fleshy fruit species significantly decreased $(\mathrm{B}=-7.730, \mathrm{P}<0.05)$ along the gradient from lowland to montane forests, while dry indehiscent fruit showed a significant increase $(B=5.595, P<0.05$ - Fig. $2 \mathrm{i})$.

As for pollination types, the percentage of the anemophilous and self-pollinating species showed a significant decrease with altitude $(\mathrm{B}=-5.923, \mathrm{P}<0.05 ; \mathrm{B}=-5.148, \mathrm{P}<$ 0.05 , respectively). As for the latter category (PSelf), this could be due to low number of self-pollinating species (7) found in the lowland forest type (Fig. 2j). On the other hand, the proportion of insect-pollinated species decreased from lowland to mid-altitude forests ( 0.612 to $0.602 \mathrm{WMP})$, and increased from mid-altitude up to the timberline forests (0.602 to $0.750 \mathrm{WMP}$ ).

The proportion of tiny seed species (classes SW1 to SW3) showed a positive correlation with elevation, increasing significantly from low to high altitudes (Fig. 2o). The proportion of small-medium sized and medium sized seeds decreased along the gradient (e.g., SW4: $\mathrm{B}=-6.981, \mathrm{P}<0.05$; SW5: $\mathrm{B}=$ $-4.421, \mathrm{P}<0.05$; SW8: $\mathrm{B}=-3.489, \mathrm{P}<0.05$ - Fig. 2 p, q). The importance of large seeds decreased (though not significantly) with elevation (Fig. 2r). On the contrary, mid-altitude pattern of variation for SW4 and SW7 was completely different, in that the proportion of seeds with $3-4 \mathrm{mg}$ and $10-20 \mathrm{mg}$ 
Fig. 2 - Variation of trait proportions along the studied elevation gradient. The weighted proportions of traits ( $\mathrm{Y}$-axis) are plotted against elevation (X-axis).
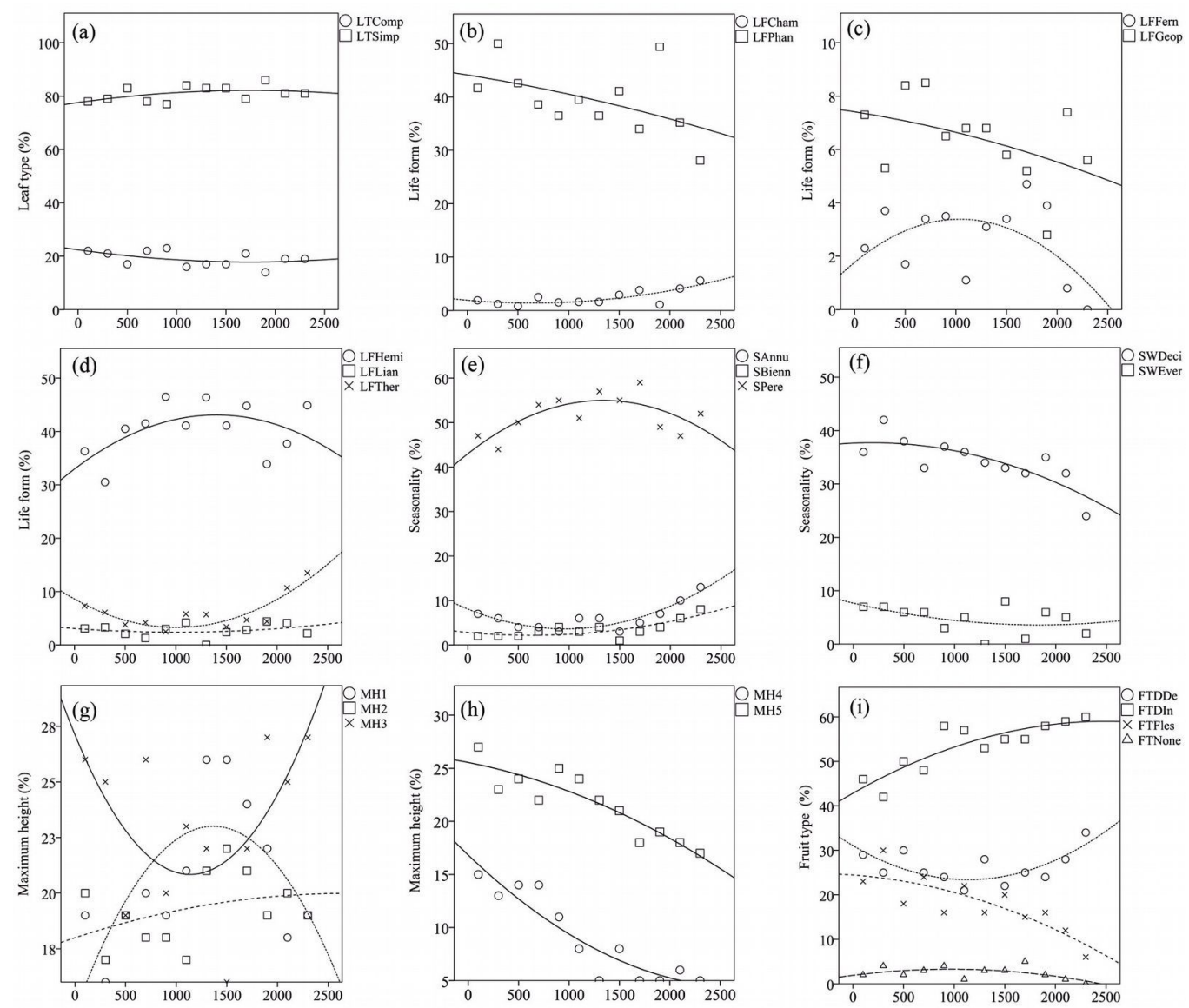

MH4
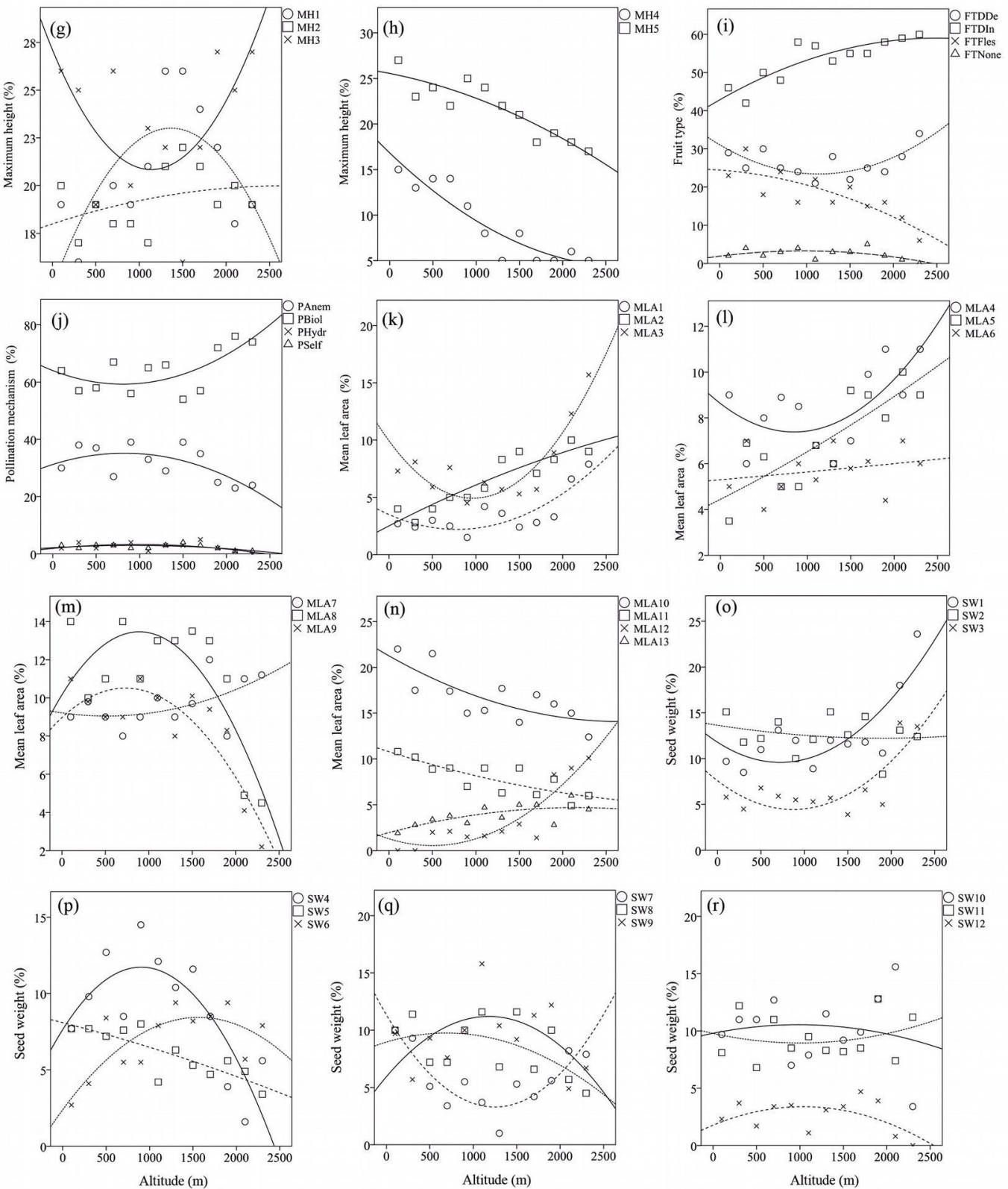

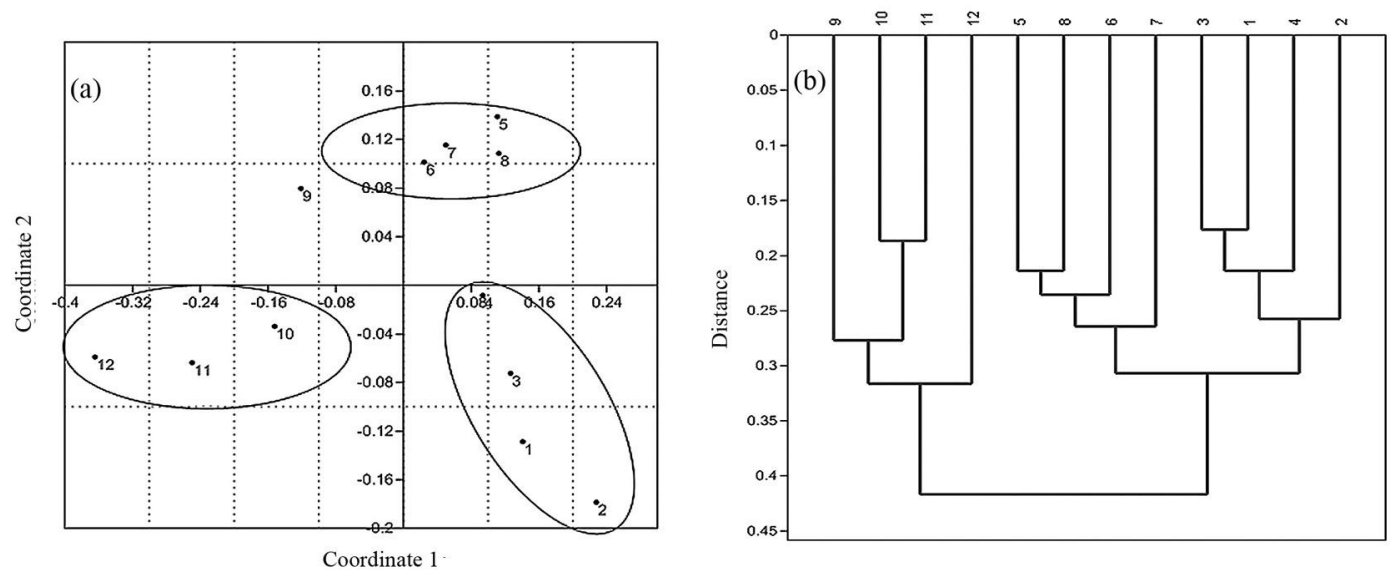

Fig. 3 - Multivariate analysis of functional turnover along the altitudinal gradient in Hyrcanian forest. Principal coordinate analysis (a) and cluster analysis (b) clearly revealed functional differences between lowland (belts1-4) and montane (belts 9-12) forest types. weight reached their maximum and minimum values at mid-altitudes, respectively.

\section{Multivariate analysis of functional diversity}

Principal coordinate analysis revealed remarkable differences among the altitudinal belts (Fig. 3a). The first two axes accounted for $73 \%$ of the total variation in functional trait composition. The first axis (variance accounted for: $52.9 \%$ ) may be clearly interpreted as related to the elevation, since belts are fairly well-distributed along this axis following a forest altitudinal gradient (1-4: lowland > 5-8: mid-altitude > 9-12: montane forest vegetation types). Contrastingly, the second coordinate (variance accounted for: $20.1 \%$ ) may be interpreted as related to both forest disturbance and diversity in structural parameters. Indeed, the second coordinate clearly separated lowland and montane forest types (belts 1-4 and 9-12) from mid-altitude plant communities (belts 5-8). Concerning belt 9 , it is characterized by a transitional vegetation type, and this may explain its intermediate position in the space of the first two coordinates.

Cluster analysis using paired-group algorithm further supported the pattern observed by the principal coordinate analysis, clearly distinguishing the three forest types (Fig. $3 b)$.

Based on the obtained results, lowland forest vegetation was more similar in functional trait composition to mid-altitude forest communities. Likely, this was due to the high number of "key" linking species shared by the mentioned vegetation types. Among shared key species with high importance values, Fagus orientalis and, to a lesser extent, Acer velutinum and Quercus castaneifolia, are worth to be mentioned. Generally, functional diversity decreased from lowland to montane forest vegetation types (Fig. 4a). Such trend fully agrees with the observed pattern for taxonomic diversity (Fig. 4b). Finally, average values of $M F A D, F D c$ and Shannon's index clearly distinguished lowland, mid-altitude and montane forest types.

\section{Discussion}

\section{Traits and altitude}

The dominance of simple leaf type species at both lowland and high altitudes is probably due to taxonomic and historical reasons. Compound leaf trait is mainly represented in this study by three different functional groups: (1) woody taxa including Albizia julibrissin Durazz., Pterocarya fraxinifolia and Gleditsia caspica Desf.; (2) ferns, for which the fronds were considered as compound leaves; (3) herbaceous taxa of Fabaceae and Rosaceae. The high importance values of these groups in lowland forests may therefore be due by the higher proportion of such taxa in lowland forest. In this study, we did not find sufficient evidences to discuss about two major theories related to evolution of compound leaf trait (rapid growth and seasonal drought hypotheses - Malhado et al. 2010). General decrease of leaf size from lowland to montane forest is probably related to the warmer, more shady and humid conditions occurring in lowland forests. Moreover, considering the observed patterns for life form and seasonality traits under the Corner's rule scenario (Corner 1949), the observed decrease in leaf size with altitude was expected to some extent. Leaf size decreases in response to stressful condition of higher altitude as compared with the resource-rich condition and fertile soil of lowland forests (Anacker et al. 2011).

Generally, phanerophytes need more humidity, deeper soils and a longer vegetative season to complete their annual growth. In contrast, chamaephyte life form is a prominent adaptation to wind and grazing stresses, and shorter season length as well. Soil depth (Doležal \& Šrutek 2002), length of the growing season (Körner 1999) and humidity (Khalili 1973) decrease with the altitude in the Hyrcanian forest. Moreover, forest openings above $1800 \mathrm{~m}$ a.s.l. imply higher wind speed and easy accessibility for grazing and trampling. As a consequence, the dominance of phanerophytes in lowland and an increasing frequency of chamaephytes along altitudinal gradients are expected based on the above ecological considerations. Altitudinal distribution of broad-leaved evergreen taxa is probably limited by the duration of low temperature period in winter which increases with altitude in the study area (Aerts 1995, van Ommen Kloeke et al. 2011). Herb layer of montane forest vegetation hosts higher proportion of therophytes, contrasting with
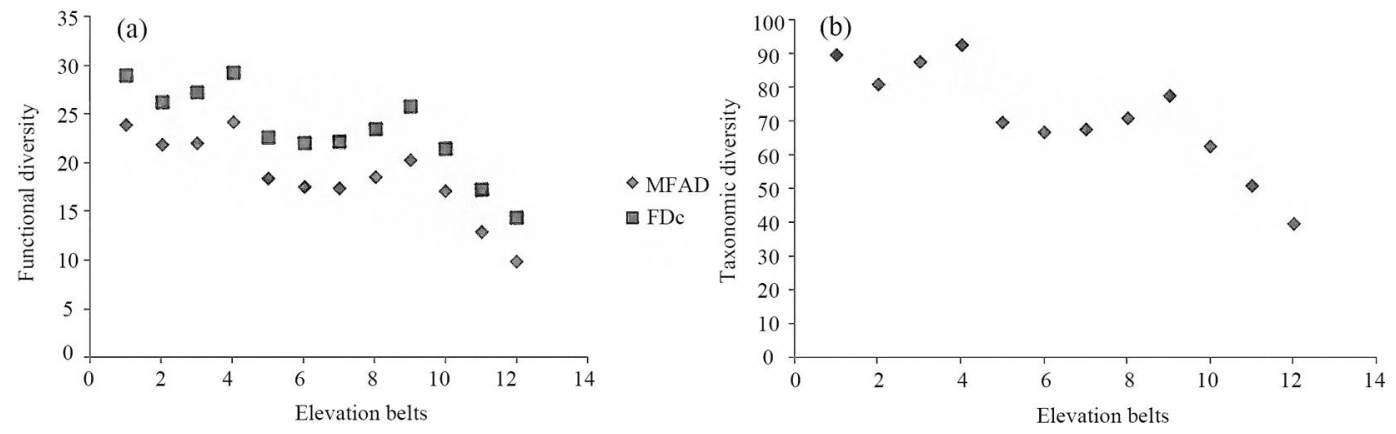

Fig. 4 - Pattern of functional (a) and taxonomic diversity (b) along the altitudinal gradient studied in the Hyrcanian forest. (MFAD): Modified Functional Attribute Diversity, $(F D c)$ : community based Functional Diversity. 
the accepted trend for high altitude ecosystems (Körner 1999). Low competition for light and disturbances (e.g., grazing and local timber harvesting) are factors favoring a higher proportion of therophytes in understory vegetation layer (McIntyre et al. 1995).

Taller plants may intercept more light in closed forest ecosystems (Ryan \& Yoder 1997, Wright et al. 2007). A decrease in plant height with elevation has been observed in several regions (Kappelle et al. 1995). However, the use of elevation as an environmental predictor of plant height is still under debate (Moles et al. 2009). Indeed, Moles et al. (2009) found that the precipitation of the wettest month was an efficient predictor of plant height. Based on such evidence, we may expect taller plants in the lowland forest types analyzed in this study. Decrease in forest density lessens the competition for light and implies high wind speed and irradiance at higher altitudes. Such factors may trigger an overall reduction of plant height, even within life form classes.

Increasing pattern of dry indehiscent fruits is clearly influenced by dominant species in montane forests (e.g., Fagus orientalis Lipsky, Carpinus orientalis Mill., Quercus macranthera Fisch. and C.A.Mey. and Acer hyrcanum Fisch. and C.A.Mey.), which mostly produce dry indehiscent fruits, especially achenes. There are two hypotheses which may explain the evolution of fleshy fruits, including fruit shift and habitat shift theories (Bolmgren \& Eriksson 2005). Central to both theories is that evolution of fleshy fruits coincides with the appearance of closed forest ecosystems in early Tertiary period. Proportion of fleshy fruits dramatically decreases from lowland closed forests to montane open forests. If the above theory holds, forest opening at higher elevations decreases the need of fruits to be a fleshy reward for dispersers. Genera belonging to the Rosaceae family, such as Crataegus, Rubus, Mespilus and Prunus, cladode-bearing plants such as Ruscus and Danae and some other groups such as Diospyros, Cornus, Celtis and Frangula, all producing fleshy fruits, are mostly abundant in lowland forests. Therefore, based on the above considerations and on the ecological costs of producing fleshy fruits, we can expect a lower frequency of such species at higher altitudes.

Anemophilous pollination depends on wind and subsequently increases with both altitude and latitude (Pallardy 2008). Pollination of anemophilous taxa in temperate deciduous forests occurs earlier than for non-anemophilous taxa, before leaf flushing (Whitehead 1984). In this study, lowland forests were dominated by anemophilous woody taxa, therefore a decreasing pattern of the wind pollination trait was observed along the elevation gradient (Friedman \& Barrett 2009). Contrastingly, biotic pollination is usually associated with closed habitats, though this trait showed non-significant changes with altitude in our study. The constant closeness of forest canopy along the elevation gradient may have contributed in this pattern.

It has been proposed that shaded environments such as tropical forest ecosystem may host species with larger seeds than less shaded habitats (Leishman \& Westoby 1994). Lowland forests in in the study area area present semi-tropical conditions such as closeness, high temperature and moisture. In addition, parameters such as plant size (Baker 1972), growth form (Levin 1974), dispersal mechanism (Lord et al. 1997), length of the growing season and primary productivity (Moles \& Westoby 2003) can influence seed mass and size. In the present study, overall larger size (e.g., higher maximum height) and longer growing season in lowland forests may favor taxa with heavier seeds. Moreover, vertebrate-dispersed species such as those carrying fleshy fruits normally carry also larger seeds (Leishman et al. 1995), which are represented in higher proportion in the lowland forest type. In contrast, tiny seeds generally increase with altitude in our study, and this may be due to a shorter growing season, stressful conditions, dominance of smaller life forms and nonvertebrates dispersers in the montane forest vegetation type (Moles et al. 2007).

\section{Functional diversity}

Diversity along environmental gradients has often been investigated (Rahbek 1995) and vegetation types are usually considered as explanatory factors (Pellissier et al. 2010). In this study, we sought for differences in trait composition and functional diversity between lowland and montane forest vegetation types. Principal coordinate analysis revealed a remarkable difference in functional trait composition among the altitudinal belts considered (Fig. 3a). Elevation seems to explain fairly well the main functional trait variation in the study area, as it can be inferred from the distribution of belts along the first axis from lowland to montane forest types. The obtained dendrogram (Fig. 3b) corroborates these results. Along with species richness (Tab. 1), trait composition in both forest types remarkably differs. Functional diversity is an indicator of the complexity of relationships between species diversity and ecosystem processes (Petchy \& Gaston 2006). Climax communities in a stable environment represent maximum capacity of interaction and complexity (Taylor 2005). In this study, lowland forests experience more stable conditions compared to the montane forest type, reflecting in a higher functional and taxonomic diversity in low altitude forests. Generally, frequency and intensity of perturbations or environ- mental stability, stressful condition, competition for light, wind speed, irradiance, biotic interactions and human interference may play key role in the emergence of specific pattern of plant traits along altitude. Variation of the above factors may favor functional difference between habitats. For eample, logging and harvesting practices may remove key plant species and consequently important functional traits, deeply affecting the ecological functioning of the Hyrcanian forest ecosystem. Therefore, along with floristic and vegetation studies, the exploration of patterns of functional diversity in this ecosystems is of utmost importance.

\section{Acknowledgments}

This research was supported by the Research Council of the University of Tehran (Iran). Data collection and taxonomic treatment was partly implemented during a research stay of SMJ at the Botanical Garden and Botanical Museum (BGBM) in Dahlem (Berlin, Germany). The authors thank the Iranian Ministry of Science, Research and Technology and BGBM for providing financial support and facilities for the research stay. Mr. Atabak Roohi is acknowledged for his help in the statistical analysis.

\section{References}

Aerts R (1995). The advantages of being evergreen. Trends in Ecology and Evolution 10 (10): 402-407. - doi: 10.1016/S0169-5347(00)891569

Akhani H, Djamali M, Ghorbanalizadeh A, Ramezani E (2010). Plant biodiversity of Hyrcanian relict forests, $\mathrm{N}$ Iran: an overview of the flora, vegetation, palaeoecology and conservation. $\mathrm{Pa}$ kistan Journal of Botany 42: 231-258. [online] URL: http:/www.edi-info.ir/files/Plant-biodiversity-of-hyrcanian-relict-forests,-in-Iran-an-overview-of-the-flora,-vegetation,.pdf

Anacker B, Rajakaruna N, Ackerly D, Harrison S, Keeley J, Vasey M (2011). Ecological strategies in California chaparral: interacting effects of soils, climate, and fire on specific leaf area. Plant Ecology and Diversity 4 (2-3): 179-188. - doi: 10.1080/17550874.2011.633573

Assadi M, Massoumi A, Khatamsaz M, Mozaffarian V (1988) Flora of Iran. Research Institute of Forest and Ranglenads publication, Tehran, Iran, vols 1-70.

Baker HG (1972). Seed weight in relation to environmental conditions in California. Ecology 53: 997-1010. - doi: 10.2307/1935413

Bakr EM (2005). A new software for measuring leaf area, and area damaged by Tetranychus urticae Koch. Journal of Applied Entomology 129: 173-175. - doi: 10.1111/j.1439-0418.2005.0094 $8 . x$

Bastl M, Burian M, Kučera J, Prach K, Rektoris L, Štech M (2008). Central European pine bogs change along altitudinal gradient. Preslia 80: 349-363.

Bolmgren K, Eriksson O (2005). Fleshy fruits, ori- 
gins, niche shifts and diversification. Oikos 109: 255-272. - doi: 10.1111/j.0030-1299.2005.126 63.x

Braun-Blanquet J (1932). Plant Sociology: the study of plant communities. McGraw-Hill, New York, USA, pp. 439.

Casanoves F, Di Rienzo JA, Diaz S (2011). FDiversity: a software package for integrated analysis of functional diversity. Methods in Ecology and Evolution 2: 233-237. - doi: 10.1111/j.2041210X.2010.00082.x

Clayton WD, Vorontsova MS, Harman KT, Williamson H (2006). GrassBase: the online world grass flora. Web site, Royal Botanical Garden, Kew, UK. [online] URL: http://www.kew. org/data/grassbase/index.html

Corner EJH (1949). The durian theory or the origin of the modern tree. Annals of Botany 13: 367-414. [online] URL: http://aob.oxfordjournals.org/content/13/4/367.extract

Cornwell WK, Ackerly DD (2009). Community assembly and shifts in plant trait distributions across an environmental gradient in coastal California. Ecological Monographs 79 (1): 109-126. - doi: 10.1890/07-1134.1

Dewan ML, Famouri J (1964). The soils of Iran FAO, Rome, Italy, pp. 319.

Diaz S, Cabido M (2001). Vive la différence: plant functional diversity matters to ecosystem processes. Trends in Ecology and Evolution 16: 646-655. - doi: 10.1016/S0169-5347(01)02283-

Diaz S, Cabido M, Casanoves F (1998). Plant functional traits and environmental filters at a regional scale. Journal of Vegetation Science 9 (1): 113-122. - doi: 10.2307/3237229

Doležal J, Šrutek M (2002). Altitudinal changes in composition and structure of mountain-temperate vegetation: a case study from Western Carpathians. Plant Ecology 158: 201-221. - doi: 10.10 23/A:1015564303206

Duckworth JC, Kent M, Ramsay PM (2000). Plant functional types: an alternative to taxonomic plant community description in biogeography? Progress in Physical Geography 24 (4) 515-542. - doi: 10.1177/030913330002400403

Fischer A, Blaschke M, Bässler C (2011). Altitudinal gradients in biodiversity research: the state of the art and future perspectives under climate change aspects. Waldökologie, Landschaftsforschung und Naturschutz 11: 35-47. [online] URL: http:/www.afsv.de/download/literatur/wa doekologie-online/waldoekologie-online heft-11 $-4 . p d f$

Friedman J, Barrett SC (2009). Wind of change: new insights on the ecology and evolution of pol lination and mating in wind-pollinated plants. Annals of Botany 103 (9): 1515-1527. - doi: 10.1093/aob/mcp035

Gaston KJ (2000). Global patterns in biodiversity. Nature 405 (6783): 220-227. - doi: 10.1038/ 35012228

Gower JC (1966). Some distance properties of latent root and vector methods used in multivariate analysis. Biometrika 53: 325-338. [online] URL: http://www.jstor.org/stable/pdfplus/2333639.pdf
Gower JC (1971). A general coefficient of similarity and some of its properties. Biometrics 27: 623-637. [online] URL: http://www.jstor.org/stable/pdfplus/2528823.pdf

Hammer O, Harper DAT, Ryan PD (2001). PASTpaleontological statistics software package for education and data analysis. Palaeontologia Electronica 4: 1-9. [online] URL: http://www.researchgate.net/publication/228393561 PASTPalaeontological_statistics_ver._1.89/file/32bfe5 135d45cd6b3b.pdf

IBM Corp (2011). IBM SPSS Statistics for Windows (version 20.0). New York, USA.

IRIMO (2012). Online database of meteorological data. Web site, Islamic Republic of Iran Meteorological Organization, Tehran, Iran. [online] URL: http:/www.irimo.ir/?newlang=eng

Jafari SM, Zarre S, Alavipanah SK (2013). Woody species diversity and forest structure from lowland to montane forest in Hyrcanian forest ecoregion. Journal of Mountain Science 10: 609620. - doi: 10.1007/s11629-013-2652-2

Khalili A (1973). Precipitation patterns of Central Alburz. Archiv für Meteorologie Geophysik und Bioklimatologie, Serie B 21: 215-232. - doi: 10. 1007/BF02243729

Kappelle M, Vanuffelen JG, Cleef AM (1995). Altitudinal zonation of montane Quercus forests along two transects in Chirripo National Park, Costa Rica. Vegetatio 119: 119-153.

Kleyer M, Bekker RM, Knevel IC, Bakker JP, Thompson K, Sonnenschein M, Poschlod P, van Groenendael JM, Klimeš L, Klimešová J, Klotz S, Rusch GM, Hermy M, Adriaens D, Boedeltje G, Bossuyt B, Dannemann A, Endels P, Götzenberger L, Hodgson JG, Jackel A-K, Kühn I, Kunzmann D, Ozinga WA, Römermann C, Stadler C, Schlegelmilch J, Steendam HJ, Tackenberg O, Wilmann B, Cornelissen JHC, Eriksson O, Garnier E, Peco B (2008). The LEDA Traitbase: a database of life-history traits of the Northwest European flora. Journal of Ecology 6: 12661274. - doi: 10.1111/j.1365-2745.2008.01430.x Klotz S, Kühn I, Durka W (2002). BIOLFLOR: Eine Datenbank mit biologisch-ökologischen Merkmalen zur Flora von Deutschland [A database of biological-ecological characteristics of the flora of Germany]. Schriftenreihe für Vegetationskunde 38: 1-334. Bundesamt für Naturschutz, Bonn, Germany. [in German] [online] URL: http://tocs.ulb.tu-darmstadt.de/11093633 7.pdf

Körner C (1999). Alpine plant life: plant ecology of high mountain ecosystems. Springer-Verlag, Berlin, Germany, pp. 344.

Körner C (2000). Why are there global gradients in species richness? Mountains might hold the answer. Trends in Ecology and Evolution 15: 513-514. - doi: 10.1016/S0169-5347(00)020048

Körner C, Donughue M, Fabbro T, Häuser C, Nogués-Bravo D, Kalin Arroyo MT, Soberon J, Speers L, Spehn EM, Sun H, Tribsch A, Tykarski P, Zbinden N (2007). Creative use of mountain biodiversity databases: the Kazbegi research agenda of GMBA-DIVERSITAS. Moun- tain Research and Development 27: 276-281. doi: $10.1659 / \mathrm{mrd} .0880$

Lavorel S, Garnier E (2002). Predicting changes in community composition and ecosystem functioning from plant traits: revisiting the Holy Grail. Functional Ecology 16: 545-556. - doi: 10.1046/j.1365-2435.2002.00664.x

Leishman MR, Westoby M (1994). The role of large seed size in shaded conditions, experimental evidence. Functional Ecology 8: 205-214. doi: $10.2307 / 2389903$

Leishman MR, Westoby M, Jurado E (1995). Correlates of seed size variation - a comparison among five temperate floras. Journal of Ecology 83: 517-529. - doi: 10.2307/2261604

Leroy AGS, Arpe K (2007). Glacial refugia for summer-green trees in Europe and south-west Asia as proposed by ECHAM3 time-slice atmospheric model simulations. Journal of Biogeography 34: 2115-2128. - doi: 10.1111/j.1365-2699. 2007.01754.x

Levin DA (1974). The oil content of seeds: an ecological perspective. American Naturalist 108: 193-206. - doi: 10.1086/282899

Lord J, Egan J, Clifford T, Jurado E, Leishman M, Williams D, Westoby M (1997). Larger seeds in tropical floras: consistent patterns independent of growth form and dispersal mode. Journal of Biogeography 24: 205-211. - doi: 10.1046/j.13652699.1997.00126.x

Malhado ACM, Whittaker RJ, Malhi Y, Ladle RJ, ter Steege H, Phillips O, Aragão LEOC, Baker TR, Arroyo L, Almeida S, Higuchi N, Killeen TJ, Monteagudo A, Pitman NCA, Prieto A, Salomão RP, Vásquez-Martínez R, Laurance WF, Ramírez-Angulo. H (2010). Are compound leaves an adaptation to seasonal drought or to rapid growth? Evidence from the Amazon rain forest. Global Ecology and Biogeography 19: 852-862. - doi: 10.1111/j.1466-8238.2010.00567.x

McIntyre S, Lavorel S, Tremont RM (1995). Plant life-history attributes: their relationship to disturbance responses in herbaceous vegetation. Journal of Ecology 83: 31-44. - doi: 10.2307/2261 148

Moles AT, Westoby M (2003). Latitude, seed predation and seed mass. Journal of Biogeography 30: 105-128. - doi: 10.1046/j.1365-2699.2003. 00781.x

Moles AT, Ackerly DD, Tweddle JC, Dickie JB, Smith R, Leishman MR, Mayfield MM, Pitman A, Wood JT, Westoby M (2007). Global patterns in seed size. Global Ecology and Biogeography 16: 109-116. - doi: 10.1111/j.1466-8238.2006. 00259.x

Moles AT, Warton DI, Warman L, Swenson NG, Laffan SW, Zanne AE, Pitman A, Hemmings FA, Leishman MA (2009). Global patterns in plant height. Journal of Ecology 97: 923-932. doi: 10.1111/j.1365-2745.2009.01526.x

Pallardy SG (2008). Physiology of woody plants ( $3^{\text {rd }}$ edn). Academic Press, San Diego, USA, pp. 454

Pellissier L, Fournier B, Guisan A, Vittoz P (2010). Plant traits co-vary with altitude in grasslands and forests in the European Alps. Plant 
Ecology 211: 351-365. - doi: 10.1007/s11258010-9794-x

Petchy OL, Gaston KJ (2006). Functional diversity: back to basics and looking forward. Ecology Letters 9: 741-758. - doi: 10.1111/j.14610248.2006.00924.x

Pla L, Casanoves F, Di Rienzo J (2012). Quantifying functional diversity. Springer-Verlag, Berlin, Germany, pp. 98. [online] URL: http://download.springer.com/static/pdf/205/bok\%3A97894-007-2648-2.pdf?auth66=1400099484_e778 690418d3569a33b71a4d0af6c16c\&ext=.pdf Poorzady M, Bakhtiari F (2009). Spatial and temporal changes of Hyrcanian forest in Iran. iForest 2: 198-206. - doi: 10.3832/ifor0515-002

Rahbek C (1995). The elevational gradient of species richness: a uniform pattern. Ecography 18: 200-205. - doi: 10.1111/j.1600-0587.1995. tb00341.x

Rechinger KH (1963). Flora Iranica. Akademische Druck und Verlagsanstal, Graz, Austria, vols. 1179.

Royal Botanical Gardens Kew (2008). Seed Information Database (SID) - version 7.1. Web site, Royal Botanical Gardens, Kew, UK. [online] URL: http://data.kew.org/sid/
Ryan MG, Yoder BJ (1997). Hydraulic limits to tree height and tree growth: what keeps trees from growing beyond a certain height? Bioscience 47: 235-242. - doi: 10.2307/1313077

Schmera D, Podani J, Eros T (2009). Measuring the contribution of community members to functional diversity. Oikos 118: 961-971. - doi: 10.11 11/j.1600-0706.2009.17076.x

Sokal RR, Rohlf FG (1995). Biometry ( $3^{\text {rd }}$ edn). W.H. Freeman and company, New York, USA, pp. 887.

Straub R (1988). Bodengesellschaften des Vorderen Orients [Soil associations of the Middle East]. Beihefte zum TAVO A 16, Wiesbaden, Germany. [in German]

Takhtajan A (1986). Floristic regions of the World. University of California Press, Berkeley \& Los Angeles, CA, USA, pp. 522.

Taylor PJ (2005). Unruly complexity: ecology, interpretation, engagement. University of Chicago Press, Chicago, IL, USA, pp. 12. [online] URL: http://works.bepress.com/cgi/viewcontent.cgi?article $=1001 \&$ context $=$ peter_taylor

van Ommen Kloeke AEE, Douma JC, Ordonez JC, Reich PB, van Bodegom PM (2011). Global quantification of contrasting leaf life spans strategies for deciduous and evergreen species in response to environmental conditions. Global Ecology and Biogeography 21: 224-235. - doi: 10.1111/j.1466-8238.2011.00667.x

Whitehead DR (1984). Wind pollination: some ecological and evolutionary perspectives. In: "Pollination Biology" (Real L ed). Academic Press, New York, NY, USA, pp. 97-108.

Wright IJ, Ackerly DD, Bongers F, Harms KE, Ibarra-Manriquez G, Martinez-Ramos M, Mazer SJ, Muller-Landau HC, Paz H, Pitman NCA (2007). Relationships among ecologically important dimensions of plant trait variations in seven Neotropical forests. Annals of Botany 99: 1003 1015. - doi: 10.1093/aob/mcl066

\section{Supplementary Material}

Appendix 1 - Species $\times$ trait matrix used for the analysis. Importance-values within the 12 elevational belts (B1-B12), trait states and values are reported.

Link: Jafari_1002@supp1001.pdf 